\title{
PENGARUH PERPUTARAN PIUTANG TERHADAP RETURN ON ASSETS (ROA) PADA PT. SUMMARECON AGUNG, Tbk.
}

\author{
Muhibah $^{1}$, Tri Septiawan Yunus ${ }^{2}$ \\ STIE Tri Dharma Nusantara \\ muhibah.stietdn@gmail.com $^{1}$, septiawantry@gmail.com ${ }^{2}$
}

\begin{abstract}
Abstrak
Penelitian ini bertujuan untuk mengetahui pengaruh perputaran piutang terhadap Return On Asset (ROA) pada PT Summarecon Agung Tbk. periode tahun 2014-2019. Penelitian ini menggunakan data kualitatif dan data kuantitatif. Sumber data yang digunakan yaitu data sekunder. Metode analisis yang digunakan adalah analisis regresi sederhana, koefisien korelasi (r) dan koefisien determinasi $\left(\mathrm{r}^{2}\right)$. Hasil penelitian menunjukkan bahwa perputaran piutang berpengaruh positif dan signifikan terhadap return on asset (ROA) pada PT. Summarecon Agung, Tbk. Berdasarkan hasil koefisien determinasi sebesar 0,946 berarti return on asstes (ROA) dipengaruhi oleh perputaran piutang sebesar $94,6 \%$ dan sisanya 5,4\% dipengaruhi oleh faktor lain yang tidak diteliti. Hipotesis dalam penelitian ini diterima.
\end{abstract}

Kata kunci : perputaran piutang, return on assets

\begin{abstract}
The purpose of this study to determine the effect of receivable turnover on Return On Assets (ROA) at PT Summarecon Agung Tbk. the period 2014-2019. This research uses qualitative data and quantitative data. The data source used is secondary data. The analysis method used is simple regression analysis, the correlation coefficient ( $r$ ) and the coefficient of determination ( $r 2)$. The results showed that receivable turnover has a positive and significant effect on return on assets (ROA) at PT. Summarecon Agung, Tbk. Based on the results of the coefficient of determination of 0.946, it means that the return on assets (ROA) is influenced by receivable turnover of $94.6 \%$ and the remaining $5.4 \%$ is influenced by other factors not examined. The hypothesis in this study is accepted.
\end{abstract}

Keywords : receivable turnover, return on assets

\section{PENDAHULUAN}

Setiap perusahaan yang bergerak di bidang dagang, jasa maupun manufaktur memiliki tujuan yang sama, yaitu memperoleh laba dan menjaga kesinambungan perusahaan di masa yang akan datang. Secara umum, keberhasilan perusahaan dalam menjalankan aktivitasnya didasarkan pada tingkat laba yang diperoleh, namun laba yang diperoleh bukan merupakan ukuran bahwa perusahaan tersebut telah bekerja secara efisien. Tingkat efesiensi dapat diketahui dengan cara membandingkan antara laba dengan modal kerja yang diinvestasikan oleh perusahaan. Untuk mencapai tujuan tersebut, diperlukan adanya modal kerja. . 
Menurut Djarwanto (2011:87), modal kerja sebaiknya tersedia dalam jumlah yang cukup agar memungkinkan perusaaahan beroperasi secara ekonomis dan tidak megalami kesulitan keuangan yang dapat membahayakan keadaan keuangan perusahaan. Periode perputaran modal kerja dimulai saat kas yang tersedia diinvestasikan dalam komponen modal kerja hingga menjadi kas, komponen modal kerja tersebut meliputi kas, piutang dan persediaan. Salah satu masalah yang dihadapi perusahaan adalah persaingan usaha dalam pemasaran produk rumah, untuk mengatasi masalah tersebut perusahaan perlu berupaya dalam merebut pasar melalui berbagai kebijakan guna meningkatkan penjualan. Sistem penjualan secara kredit yang dilakukan perusahaan merupakan salah satu usaha dalam rangka untuk meningkatkan volume penjualan. Penjualan kredit tidak segera dapat menghasilkan penerimaan kas, tetapi menimbulkan apa yang disebut dengan piutang. Sehingga dapat ditagih apabila telah jatuh tempo dari tanggal yang ditentukan.

Penjualan barang dan jasa pada banyak perusahaan saat ini dilakukan dengan kredit. Piutang timbul karena adanya tenggang waktu antara pembelian dan pembayaran. Menurut Kieso, et al. (2007:346) piutang adalah klaim uang, barang atau jasa kepada pelanggan atau pihak-pihak lainnya. Selain itu Baridwan (2011:124) menjelaskan bahwa piutang usaha menunjukkan piutang yang timbul dari penjualan barang-barang atau jasajasa yang dihasilkan perusahaan.

Perputaran piutang merupakan bagian yang terpenting dalam perusahaan sebab perputaran piutang dapat meningkatkan profitabilitas. Selama perusahaan beroperasi piutang akan selalu dalam keadaan berputar. Menurut Sawir (2005:198) semakin besar perputaran piutang maka semakin besar resiko, tetapi bersamaan dengan itu memperbesar profitabilitasnya. Dimana dalam penelitian ini indikator yang digunakan dalam mengukur profitabilitas adalah Return on Asset (ROA). Alasan memilih rasio ROA karena dapat memperhitungkan kemampuan perusahaan dalam memperoleh laba secara keseluruhan. Menurutu Tandelilin (2010:372) Return On Asset (ROA) menggambarkan sejauh mana kemampuan asset-aset yang dimiliki perusahaan bias menghasilkan laba. Sehingga dapat disimpukan bahwa semakin besar Return On Asset (ROA) semakin besar pula keuntungan yang diperoleh perusahaan dan semakin baik perusahaan tersebut dari segi penggunaan asset. Selain itu disebabkan karena dalam beberapa penelitian sebelumnya, umumnya sebagian besar menggunakan rasio keuangan return on asset (ROA). Serta dari hasil pengamatan dari beberapa peneliti sebelumnya ditemukan tidak konsistensinya hasil penelitian sebelumnya diperoleh riset gap dari hasil penelitian mengenai Return On Asset (ROA).

Lucky Nugroho (2019) menemukan bahwa perputaran piutang berpengaruh negatif dan tidak signifikan terhadap return on assets. Hasil serupa ditemukan oleh Ela Widasari (2017) dimana perputaran piutang berpengaruh negatif dan signifikan terhadap return on assets. Pieter Tion (2017) menemukan bahwa perputaran piutang berpengaruh positif dan signifikan terhadap return on assets. Penelitian yang dilakukan oleh Feibe Teresa Budiang (2017) juga menemukan pengaruh yang positif antara perputaran piutang dan return on assets. 
Berdasarkan hasil penelitian sebelumnya, diperoleh riset karena adanya perbedaan penelitian sebelumnya mengenai pengaruh perputaran piutang terhadap profitabilitas. Sehingga hal ini yang menjadi permasalahan penelitian mengenai tingkat perputaran piutang terhadap profitabilitas perusahaan.

\section{Piutang}

Piutang adalah klaim atas uang, barang, atau jasa kepada pelanggan atau pihakpihak lainnya. Piutang usaha pada umumnya adalah kategori yang paling signifikan dari piutang dan merupakan hasil dari aktivitas normal perusahaan atau entitas, yaitu penjualan barang atau jasa secara kredit kepada pelanggan. Piutang usaha dapat diperkuat dengan janji pembayaran tertulis secara formal dan diklasifikasikan sebagai wesel tagih (notes receivable). Piutang usaha umumnya merupakan jumlah dari material di neraca bila dibandingkan dengan piutang non usaha, diperoleh jumlah piutang usaha perusahaan, untuk diolah datanya.

Menurut Setiawan (2010:199), piutang usaha adalah segala bentuk tagihan atau klaim perusahaan kepada pihak lain yang pelunasannya dapat dilakukan dalam bentuk uang, barang, maupun jasa. Martono dan Harjito (2011 : 95) berpendapat bahwa piutang merupakan tagihan perusahaan kepada pelanggan/pembeli atau pihak lain yang membeli produk perusahaan.

Definisi di atas menerangkan bahwa kebijakan penjualan kredit ini merupakan kebijakan yang biasa dilakukan dalam dunia bisnis untuk merangsang minat para langganan. Jadi kebijakan ini sengaja dilakukan untuk memperluas pasar dan memperbesar hasil penjualan. Tentu saja dengan kebijakan penjualan kredit ini akan menimbulkan risiko bagi perusahaan akan tidak dapat ditagihkan sebagian atau bahkan mungkin seluruh dari piutang tersebut. Oleh karena itu maka lalu memperhitungkan biaya atas risiko tidak dapat ditagihnya piutang tersebut dalam bentuk bad debt expense.

Menurut Fess dan Warren (2008:356) jenis-jenis piutang diklasifikasikan sebagai berikut :

\section{Piutang usaha}

Transaksi paling umum yang menciptakan piutang adalah penjualan barang dagang atau jasa secara kredit. Piutang dicatat dengan mendebit akun piutang usaha. Piutang usaha diklasifikasikan di neraca sebagai aktiva lancar.

2. Wesel tagih

Wesel tagih (notes receivable) adalah jumlah yang terutang bagi pelanggan disaat perusahaan telah menerbitkan surat utang formal. Sepanjang wesel tagih diperkirakan akan tertagih dalam setahun, maka biasanya diklasifikasikan dalam neraca sebagai aktiva lancar.

3. Piutang lain-lain

Piutang lain-lain biasanya disajikan secara terpisah dalam neraca. Jika piutang ini diharapkan akan tertagih dalam satu tahun, maka piutang tersebut diklasifikasikan sebagai aktiva lancar. Jika penagihannya lebih dari satu tahun, maka piutang ini 
diklasifikasikan sebagai aktiva tidak lancar dan dilaporkan dibawah judul investasi. Piutang selalu dalam keadaan berputar, Periode perputarannya atau periode terikatnya modal dalam piutang adalah tergantung kepada syarat pembayarannya. Makin lemah atau makin lama syarat pembayarannya, berarti makin lama modal akan tertentu terikat pada piutang.

\section{Perputaran Piutang}

Menurut Riyanto (2008: 90), perputaran piutang adalah rasio yang memperlihatkan lamanya waktu untuk mengubah piutang menjadi kas. Tingkat perputaran piutang (receivable turnover) dapat diketahui dengan membagi penjualan kredit bersih dengan saldo rata-rata piutang. Piutang yang dimiliki oleh suatu perusahaan mempunyai hubungan erat dengan volume penjualan kredit. Posisi piutang dapat dihitung dengan menggunakan rasio perputaran piutang, sehingga dapat diketahui seberapa besar pengaruh piutang tersebut.

Dari pengertian yang telah diuraikan di atas, dapat disimpulkan bahwa perputaran piutang terdiri dari dua variabel yaitu total penjualan kredit dan rata-rata piutang, dikalikan dengan 100\% sehingga kita dapat mengetahui berapa besar pengaruhnya.

Sartono (2008:44) mengatakan bahwa kecepatan penerimaan hasil piutang dalam satu periode (perputaran piutang) akan dapat mempengaruhi likuiditas perusahaan karena pertukaran piutang lebih cepat dari yang diharapkan dan seberapa jauh piutang perusahaan bisa dipakai untuk memenuhi jangka pendeknya. Sehingga ketika likuiditas perusahaan terbentuk maka keadaan kondisi aktiva perusahaan akan semakin baik. Membaiknya kondisi aktiva perusahaan yang dalam kesempatan ini berfokus pada aktiva lancar yang disebabkan dari adanya piutang, tentu akan memberikan andil yang sangat besar pada seluruh atau sebagian aktivitas perusahaan. Dengan terakomodirnya aktivitas perusahaan maka profitabilitas perusahaan akan meningkat.

Piutang dalam neraca timbul kerena adanya penjualan barang dagang secara kredit. Semakin longgar persyaratan kredit yang diberikan, akan semakin besar pula jumlah penjualan. Sebaliknya, semakin ketat persyaratannya diberlakukan, kemungkinan pelanggan akan beralih kepada pesaing sehingga penjualan menjadi berkurang. Investasi dalam piutang ditentukan dengan membandingkan keuntungan yang diperoleh dari tingkat investasi tertentu dengan biaya yang akan dikeluarkan oleh karena memiliki tingkat investasi tersebut.

Dalam proses penerimaan piutang, untuk melihat kelancaran penerimaannya dan pengukuran baik tidaknya investasi dalam piutang dapat diketahui dari tingkat perputarannya. Karena piutang (receivables) ini merupakan elemen modal kerja yang juga selalu dalam keadaan baik.

Menurut Riyanto (2010:90) yang menyatakan bahwa : "Tingkat perputaran piutang (receivable turnover) dapat diketahui dengan membagi jumlah credit sales selama periode tertentu dengan jumlah rata-rata piutang (average receivable)". 
Berdasarkan pengertian di atas, maka pengertian perputaran piutang dapat didefinisikan sebagai alat pengukuran dalam proses penilaian piutang usaha sehingga dapat dilihat berapa kali piutang usaha tersebut dalam dikonversikan menjadi kas selama periode tertentu. Penjualan disini adalah semua penjualan kredit sesudah dikurangi potongan-potongan, sedangkan piutang adalah jumlah piutang di perusahaan.

Penjualan yang dilakukan secara kredit oleh suatu perusahaan secara otomatis akan mempengaruhi tingkat perputaran piutangnya. Naik turunnya perputaran piutang dalam suatu perusahaan banyak dipengaruhi oleh berbagai macam faktor, baik faktor internal maupun eksternal. Menurut Kasmir (2008: 188) menyatakan bahwa perputaran piutang menunjukkan berapa kali suatu perusahaan menagih piutangnya dalam satu periode atau kemampuan dana yang tertanam dalam piutang berputar dalam suatu periode tertentu. Rasio ini menggambarkan efisiensi perusahaan dalam mengelola piutangnya. Tingkat perputaran piutang diukur dengan membandingkan antara penjualan kredit dengan ratarata piutangnya.

Menurut Kasmir (2008: 176) menyatakan tingkat perputaran piutang yang tinggi berarti semakin cepat dana yang diinvestasikan pada piutang dapat ditagih menjadi uang tunai atau menunjukkan modal kerja yang ditanam dalam piutang rendah. Sebaliknya jika tingkat perputaran piutang yang rendah berarti piutang membutuhkan waktu yang lebih lama untuk dapat ditagih menjadi uang tunai atau menunjukkan modal kerja yang ditanam dalam piutang lebih besar.

Dapat disimpulkan dari pengertian-pengertian diatas, bahwa perputaran piutang merupakan salah satu rasio dari rasio aktivitas yang mana digunakan untuk melihat berapa kali, seberapa cepat piutang dapat tertagih dengan cara membandingkan penjualan kredit bersih di bagi dengan rata-rata piutang dan rata atau penjualan bersih perusahaan di bagi dengan piutang dagang.

Semakin tinggi perputaran piutang menjelaskan bahwa semakin baik perusahaan dalam menagih proses piutang usaha, serta menunjukkan modal kerja yang disimpan dalam piutang usaha rendah. Sebaliknya, jika rendahnya perputaran piutang dalam perusahaan menjelaskan bahwa modal kerja yang disimpan terlalu banyak dan menunjukkan bahwa bagian penagihan piutang usaha tidak berjalan efektif, maka perputaran piutang diharapakn dapat berputar secara maksimal.

Dengan demikian, berdasarkan uraian diatas maka dapat disimpulkan bahwa perputaran piutang harus dimaksimalkan dalam proses manajemennya agar dapat berjalan efektif dan efisien.

\section{Profitabilitas}

Sebelum mengambil keputusan seorang manajer keuangan harus mengetahui terlebih dahulu bagaimana kondisi keuangan perusahaan saat itu. Kondisi keuangan perusahaan yang disajikan dalam bentuk laporan keuangan dapat dijadikan pertimbangan manajer keuangan dengan melakukan analisis terlebih dahulu terhadap laporan keuangan tersebut. Tingkat profitabilitas yang tinggi pada sebuah perusahaan akan meningkatkan 
daya saing antarperusahaan. Perusahaan yang memperoleh tingkat keuntungan yang tinggi akan mampu membuka cabang yang baru serta memperluas usahanya dengan membuka investasi baru yang terkait dengan perusahaan induknya. Tingkat keuntungan yang tinggi menandakan pertumbuhan perusahaan pada masa mendatang. Profitabilitas dinilai sangat penting, karena untuk melangsungkan hidup suatu perusahaan haruslah berada dalam keadaan menguntungkan atau profitable. Tanpa keuntungan maka sulit bagi perusahaan untuk menarik modal dari luar. Berikut beberapa pengertian tentang profitabilitas Menurut Sartono (2010:122) menyatakan bahwa profitabilitas adalah kemampuan perusahaan memperoleh laba dalam hubungannya dengan penjualan total aktiva maupun modal sendiri. Profitabilitas suatu perusahaan menunjukkan perbandingan antara laba dengna aktiva atau modal yang menghasilkan laba tersebut.

Dengan kata lain profitabilitas menurut Riyanto (2008:35) adalah kemampuan perusahaan untuk menghasilkan laba selama periode tertentu, dalam mewujudkan untuk memperoleh keuntungan perusahaan agar memperhatikan hal tersebut.

Menurut Kasmir (2011:196) menyatakan bahwa rasio profitabilitas merupakan rasio untuk menilai kemampuan perusahaan dalam mencari keuntungan dalam memberikan ukuran tingkat efektifitas manajemen perusahaan, hal ini ditunjukkan dari laba yang diperoleh dan pendapatan investasi.

Berdasarkan pendapat para ahli tersebut dapat ditarik kesimpulan bahwa profitabilitas adalah kemampuan suatu perusahaan menghasilkan laba dari proses kegiatan bisnis perusahaan melalui berbagai keputusan dan kebijakan manajemen. Perusahaan akan mengalami kesulitan menarik modal dari luar jika dalam kondisi menguntungkan (profitable).

Terdapat beberapa jenis rasio profitabilitas yang dapat digunakan untuk menilai serta mengukur posisi keuangan perusahaan dalam satu periode tertentu sehingga didalam menentukan tingkat profitabilitas perusahaan ada yang perlu diketahui. Sartono (2010:113) mengelompokkan rasio profitablitas ke dalam tiga jenis rasio yaitu :

\section{Profit Margin}

2. Return on Assets (ROA)

3. Return on Equity (ROE)

\section{Return on Assets (ROA)}

Return on Asset (ROA) merupakan rasio yang menunjukkan hasil (return) atas jumlah aktiva yang digunakan dalam perusahaan. Return on Asset (ROA) merupakan suatu ukuran tentang efektifitas manajemen dalam mengelola investasinya.

Disamping itu hasil pengembalian investasi menunjukkan produktifitas dari seluruh dana perusahaan, baik modal pinjaman maupun modal sendiri. Semakin rendah (kecil) rasio ini digunakan untuk mengukur efektifitas dari keseluruhan operasi perusahaan.

Menurut Hanafi dan Halim (2016:157), return on asset (ROA) yaitu mengukur kemampuan perusahaan menghasilkan laba dengan menggunakan total aset (kekayaan) 
yang dipunyai perusahaan setelah disesuaikan dengan biaya-biaya untuk mendanai asset tersebut.

Dari pengertian diatas dapat disimpulkan bahwa Return on Asset (ROA) itu sendiri adalah salah satu bentuk rasio profitabilitas yang dimaksudkan untuk dapat mengukur kemampuan perusahaan dengan keseluruhan dana yang ditanamkan dalam aktiva yang digunakan untuk operasi perusahaan (net operating income) dengan jumlah investasi atau aktiva yang digunakan untuk menghasilkan keuntungan operasi tersebut (net operating asset).

Munawir (2002:85) menyatakan bahwa ROA memiliki beberapa manfaat yaitu antara lain:

1. Jika perusahaan telah menjalankan praktik akuntansi dengan baik maka dengan analisis Return on Asset (ROA) dapat mengukur efisiensi penggunaan modal yang menyeluruh, yang sensitif terhadap setiap hal yang mempengaruhi keadaan keuangan perusahaan.

2. Dapat diperbandingkan dengan rasio industri sehingga dapat diketahui posisi keuangan perusahaan terhadap industri. Hal ini merupakan salah satu langkah dalam perencanaan strategi.

3. Selain berguna untuk kepentingan kontrol, analisis Return on Asset (ROA) juga berguna untuk kepentingan perencanaan.

Menurut Munawir (2002:89) bahwa ada dua faktor yang mempengaruhi Return on Asset (ROA) yaitu sebagai berikut :

1. Turn over operating asset yaitu tingkat perputaran aktiva yang dipergunakan untuk operasi perusahaan sehingga aktiva digunakan sebagaimana mestinya.

2. Profit margin yaitu besarnya keuntungan operasi dan jumlah penjualan bersih. ROA atau ROI merupakan rasio pengukuran profitabilitas yang sering digunakan oleh manajer keuangan untuk mengukur efektifitas keseluruhan dalam menghasilkan laba dengan aktiva yang tersedia. Berdasarkan hal ini, maka faktor yang mempengaruhi profitabilitas adalah laba bersih setelah pajak, penjualan bersih dan total aset.

\section{Hubungan Perputaran Piutang dan Return on Assets (ROA)}

Perputaran piutang merupakan bagian yang terpenting dalam perusahaan sebab perputaran piutang dapat meningkatkan profitabilitas. Selama perusahaan beroperasi piutang akan selalu dalam keadaan berputar. Menurut Sawir (2005:198) semakin besar perputaran piutang maka semakin besar resiko, tetapi bersamaan dengan itu memperbesar profitabilitasnya. Ketika perputaran piutang semakin cepat maka semakin cepat pula menjadi kas dan akan dapati digunakan untuk melangsungkan kegiatan operasional perusahaan dan begitupula sebaliknya.

Menurut Riyanto (2016:89) menyatakan bahwa tinggi rendahnya receivables turnover mempunyai efek yang langsung terhadap besar kecilnya modal yang diinvestasikan dalam piutang. Makin tinggi turnovernya, berarti makin cepat perputarannya. Tingkat perputaran piutang yang tinggi akan mendukung perusahaan dalam kegiatan operasional, sehingga perusahaan dapat memaksimalkan Return On Asset 
(ROA). Dan sebaliknya tingkat perputaran piutang yang rendah akan menghambat perusahaan dalam kegiatan operasional, sehingga perusahaan kurang dapat memaksimalkan laba serta Return On Asset (ROA). Membaiknya kondisi aktiva perusahaan yang dalam kesempatan ini berfokus pada aktiva lancar yang disebabkan dari adanya piutang, tentu akan memberikan andil yang sangat besar.

\section{Hipotesis}

H1 = diduga perputaran piutang berpengaruh positif dan signifikan terhadap return on assets (ROA) pada PT. Summarecon Agung, Tbk.

\section{METODE PENELITIAN}

\section{Jenis dan Sumber Data}

Adapun jenis data yang digunakan dalam penelitian ini adalah data kualitatif, yaitu data yang diperoleh dari perusahaan dalam bentuk informasi baik secara lisan maupun tertulis seperti gambaran singkat, struktur organisasi dan aktivitas usaha. Dan data kualitatif, yaitu data yang diperoleh dari perusahaan dalam bentuk angka seperti laporan keuangan perusahaan.

Sumber data yaitu data sekunder, data yang diperoleh dari dokumen perusahaan yang berupa laporan tertulis yang dibuat secara berkala seperti laporan keuangan.

\section{Variabel Penelitian}

Menurut Sugiyono (2016:58), variabel penelitian pada dasarnya adalah segala sesuatu yang berbentuk apa saja yang ditetapkan oleh peneliti untuk dipelajari sehingga diperoleh informasi tentang hal tersebut, kemudian ditarik kesimpulannya. Variabel merupakan indikator terpenting yang menentukan keberhasilan suatu penelitian karena variabel penelitian adalah objek penelitian atau titik perhatian dalam suatu penelitian. Adapun variabel dalam penelitian ini adalah perputaran piutang dan return on assets (ROA) pada PT. Summarecon Agung, Tbk.

\section{Definisi Operasional dan Pengukurannya}

1. Perputaran piutang, merupakan alat pengukuran dalam proses penilaian piutang usaha sehingga dapat dilihat berapa kali piutang tersebut dikonversikan menjadi kas selama periode tertentu.

Perputaran piutang $=\frac{\text { penjualan }}{\text { piutang }}$

2. Retutn on Assets (ROA), menunjukkan kemampuan total aset dalam menghasilkan keuntungan yang tersedia bagi pemegang saham.

Return on Assets $(\mathrm{ROA})=\frac{\text { Laba Bersih }}{\text { Total Aktiva }}$

\section{Metode Analisis Data}

1. Analisis Regresi Linear Sederhana 
Analisis regresi linear sederhana digunakan untuk mengukur hubungan variabel dependen, dimana pada penelitian ini financial leverage sebagai variabel independen dan earing per share sebagai variabel dependen. Formulanya yaitu :

$$
Y=a+b x
$$

Keterangan:

Y: variabel dependen

a: bilangan konstanta

b: koefisien variabel $\mathrm{x}$

$\mathrm{x}$ : variabel independen

Nilai a dan $\mathrm{b}$ dapat dihitung dengan menggunakan rumus dibawah ini:

$$
\begin{gathered}
a=\frac{\left(\sum y\right)\left(\sum x^{2}\right)-\left(\sum x\right)\left(\sum x y\right)}{n\left(\sum x^{2}\right)-\left(\sum \mathrm{x}\right)^{2}} \\
b=\frac{n\left(\sum x y\right)-\left(\sum x\right)\left(\sum y\right)}{n\left(\sum x^{2}\right)-\left(\sum x\right)^{2}}
\end{gathered}
$$

\section{Koefisien Korelasi (r)}

Korelasi merupakan istilah yang digunakan untuk mengukur kekuatan hubungan antar variabel. Menurut Hasan (2014:228) "Analisis korelasi adalah cara untuk mengetahui ada atau tidak adanya hubungan antar variabel misalnya hubungan dua variabel". Apabila terdapat hubungan antarvariabel maka perubahan-perubahan yang terjadi pada salah satu variabel akan mengakibatkan terjadinya perubahan pada variabel lainnya.. Koefisien korelasi linear dengan metode least aquare dapat digunakan rumus berikut:

$$
\boldsymbol{r}=\frac{\mathbf{n} \sum \mathbf{x y}-\left(\sum \mathbf{x}\right)\left(\sum \mathbf{y}\right)}{\sqrt{\left\{n \Sigma x^{2}-(\Sigma x)^{2}\right\}\{n \Sigma y 2-(\Sigma y) 2\}}}
$$

$\mathrm{n}$ = Banyaknya Pasangan data $\mathrm{X}$ dan $\mathrm{Y}$

$\Sigma \mathrm{x}=$ Total Jumlah dari Variabel $\mathrm{X}$

$\Sigma \mathrm{y}=$ Total Jumlah dari Variabel Y

$\Sigma \mathrm{x}^{2}=$ Kuadrat dari Total Jumlah Variabel $\mathrm{X}$

$\Sigma \mathrm{y}^{2}=$ Kuadrat dari Total Jumlah Variabel Y

$\Sigma x y=$ Hasil Perkalian dari Total Jumlah Variabel X dan Variabel Y

3. Koefisien Determinasi $\left(r^{2}\right)$

Koefisien determinasi yang biasanya dinyatakan dengan $r^{2}$ adalah angka yang menunjukkan variasi variabel dependen yang dijelaskan oleh variasi variabel independen. $\mathrm{r}^{2}$ merupakan besaran non negatif dan besarna koefisien determinas adalah antara 0-1. Berikut rumus koefisien determinasi :

$$
\mathrm{KD}=\text { r.r }
$$

4. Uji Hipotesis 
Uji t dikenal dengan uji parsial yaitu untuk menguji bagaimana pengaruh masingmasing variabel bebasnya secara sendiri-sendiri terhadap variabel terikatnya. Pengujian hipotesis dimaksudkan sebagai cara untuk menentukan apakah suatu hipotesis tersebut sebaiknya diterima atau ditolak. Pada penelitian ini nilai t hitung akan dibandingkan dengan $t$ tabel pada tingkat signifikan $(\alpha)=5 \%$. Untuk menentukan $t$ hitung dengan menggunakan rumus :

Keterangan :

$$
t=\frac{r \sqrt{n-2}}{\sqrt{1-r^{2}}}
$$

$\mathrm{t}: \mathrm{t}$ hitung

r: koefisien korelasi

$\mathrm{n}$ : jumlah data

Uji hipotesis untuk untuk uji $t$ adalah sebagai berikut :

$\mathrm{H}_{0}: \beta=0$, tidak ada hubungan antara variabel $\mathrm{X}$ dan $\mathrm{Y}$

$\mathrm{H}_{0}: \beta \neq 0$, ada hubungan antara variabel $\mathrm{X}$ dan $\mathrm{Y}$

Proses pengujian dilakukan dengan melihat tabel uji parsiol dengan memperhatikan kolom signifikansi dan nilai thitung dan membandingkan dengan taraf signifikasi $\alpha=0,05$. Adapun dasar pengambilan keputusannya yaitu :

1) Jika nilai signifikansi $<0,05$ dan $t_{\text {hitung }}>t_{\text {tabel }}$ maka $\mathrm{H}_{0}$ ditolak $\mathrm{H}_{1}$ diterima.

2) Jila nilai signifikansi $>0,05$ dan $t_{\text {hitung }}<t_{\text {tabel }}$ maka $\mathrm{H}_{0}$ diterima $\mathrm{H}_{1}$ ditolak.

\section{HASIL PENELITIAN DAN PEMBAHASAN Perputaran Piutang}

Perputaran piutang, merupakan alat pengukuran dalam proses penilaian piutang usaha sehingga dapat dilihat berapa kali piutang tersebut dikonversikan menjadi kas selama periode tertentu. Perputaran piutang dihitung dengan membagikan antara penjualan dan piutang setiap periode. Di bawah ini merupakan perhitungan perputaran piutang pada PT. Summarecon Agung, Tbk.

Tabel 1 . Perputaran piutang PT Summarecon Agung,Tbk. Tahun 2014-2019

\begin{tabular}{|c|c|c|c|}
\hline Tahun & Penjualan & Piutang & $\begin{array}{c}\text { Perputaran Piutang } \\
\text { (Kali) }\end{array}$ \\
\hline 2014 & 5.333 .593 .142 .000 & 86.323 .820 .000 & 61,78 \\
\hline 2015 & 5.623 .560 .624 .000 & 152.036 .034 .000 & 36,98 \\
\hline 2016 & 5.397 .948 .907 .000 & 548.310 .415 .000 & 9,84 \\
\hline 2017 & 5.640 .751 .810 .000 & 698.990 .644 .000 & 8,06 \\
\hline 2018 & 5.661 .360 .114 .000 & 454.875 .052 .000 & 12,45 \\
\hline 2019 & 5.941 .625 .762 .000 & 291.197 .343 .000 & 20,40 \\
\hline
\end{tabular}

Sumber : data diolah, 2020

Return on Assets (ROA) 
Retutn on Assets (ROA) menunjukkan kemampuan total aset dalam menghasilkan keuntungan yang tersedia bagi pemegang saham. Return on assets (ROA) dihitung dengan membandingkan antara laba bersih dan total asset yang dimiliki perusahaan setiap periodenya. Di bawah ini merupakan perhitungan return on assets (ROA) pada PT. Summarecon Agung, Tbk.

Tabel 2. Return on Assets (ROA) pada PT. Summarecon Agung, Tbk.

\begin{tabular}{|c|c|c|c|}
\hline Tahun & Laba Bersih & Total Aset & ROA (\%) \\
\hline 2014 & 1.387 .5165 .904 .000 & 15.379 .478 .994 .000 & 9,02 \\
\hline 2015 & 1.064 .079 .939 .000 & 18.758 .262 .022 .000 & 5,67 \\
\hline 2016 & 605.050 .858 .000 & 20.810 .319 .657 .000 & 2,90 \\
\hline 2017 & 532.437 .613 .000 & 21.662 .950 .720 .000 & 2,45 \\
\hline 2018 & 690.623 .630 .000 & 23.299 .242 .068 .000 & 2,96 \\
\hline 2019 & 613.020 .426 .000 & 24.441 .657 .276 .000 & 2,51 \\
\hline
\end{tabular}

Sumber : data diolah, 2020

\section{Analisis Regresi Linear Sederhana}

Tabel 3. Koefisien Regresi

\begin{tabular}{|c|c|c|c|c|c|c|}
\hline \multicolumn{7}{|c|}{ Coefficients $^{a}$} \\
\hline \multirow{2}{*}{\multicolumn{2}{|c|}{ Model }} & \multicolumn{2}{|c|}{ Unstandardized Coefficients } & $\begin{array}{c}\text { Standardized } \\
\text { Coefficients }\end{array}$ & \multirow[b]{2}{*}{$\mathrm{t}$} & \multirow[b]{2}{*}{ Sig. } \\
\hline & & $\mathrm{B}$ & Std. Error & Beta & & \\
\hline 1 & (Constant) & 1.209 & .456 & & 2.651 & .057 \\
\hline & perputaranpiutang & .122 & .015 & .973 & 8.407 & .001 \\
\hline
\end{tabular}

a. Dependent Variable: roa

Sumber : data diolah, 2020

Berdasarkan hasil SPSS di atas, diperoleh persamaan regresi $\mathrm{Y}=1,209+0,122 \mathrm{X}$.

Nilai (constant) menunjukkan nilai sebesar 1,209 artinya jika nilai variabel independen (perputaran piutang) nol maka nilai variabel dependen (roa) sebesar 1,209.

Nilai variabel perputaran piutang menunjukkan tanda positif yang berarti setiap kenaikan 1 satuan pada perputaran piutang maka akan menaikkan nilai return on assets (ROA) sebesar 0,122.

\section{Koefisien Korelasi dan Determinasi}

Tabel 4. Hasil koefisien korelasi dan determinasi 


\section{AkMen}

Volume 17 Nomor 3 September 2020

Hal. 464 - 476

e-ISSN : 2621-4377 \& p-ISSN : 1829-8524

Hbmepage: https//e-jurnal.stienobel-indonesiaacid/index.php/akmen

\begin{tabular}{|l|r|r|r|r|}
\hline Model & R & R Square & Adjusted R Square & Std. Error of the Estimate \\
\hline 1 & $.973^{\mathrm{a}}$ & .946 & .933 & .680 \\
\hline
\end{tabular}

a. Predictors: (Constant), perputaranpiutang

Sumber : data diolah, 2020

Berdasarkan hasil analisis diperoleh nilai koefisien korelasi $(r)=0,973$ sehigga dapat disimpulkan bahwa terdapat pengaruh yang sangat kuat antara perputaran piutang dan return on assets (ROA).

Hasil determinasi $\left(\mathrm{r}^{2}\right)$ sebesar 0,946 yang berarti bahwa perputaran piutang mampu mempengaruhi return on assets (ROA) sebesar 94,6\% dan sisanya 5,4\% dipengaruhi oleh faktor lain yang tidak diteliti.

\section{Uji Hipotesis (Uji-t)}

Tabel 5. Hasil uji t

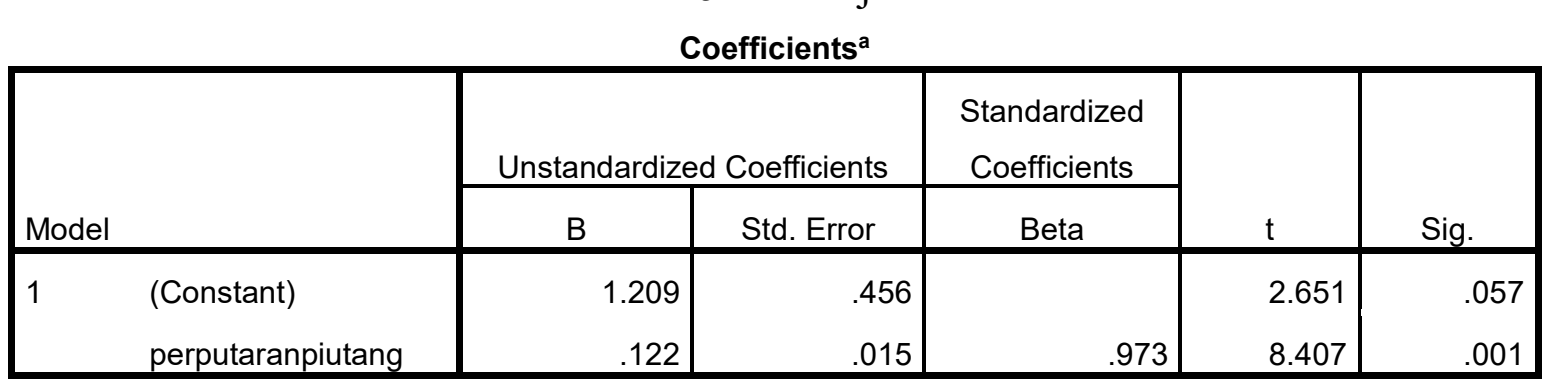

a. Dependent Variable: roa

Sumber : data diolah, 2020

Hasil uji hipotesis (uji-t) diperoleh nilai $t_{\text {hitung }}$ sebesar 8,407 $>\mathrm{t}_{\text {tabel }} 2,131$ dengan nilai signifikansi sebesar $0,001<0,05$ sehingga tolak $\mathrm{H}_{0}$ dan terima $\mathrm{H}_{\mathrm{a}}$. Sehingga dapat disimpulkan bahwa terdapat pengaruh signifikan antara perputaran piutang terhadap return on assets (ROA) pada PT. Summarecon Agung, Tbk.

\section{KESIMPULAN}

Berdasarkan hasil penelitian dan pembahasan yang telah diuraikan sebelumnya, maka dapat disimpulkan sebagai berikut :

1. Persamaan analisis regresi linear sederhana $\mathrm{Y}=1,209+0,122 \mathrm{X}$ menunjukkan adanya hubungan yang positif antara perputaran piutang dan return on assets (ROA) pada PT. Summarecon Agung, Tbk.

2. Hasil perhitungan koefisien korelasi (r) 0,973 menujukkan hubungan yang sangat kuat. Dan diperoleh nilai koefisien determinasi sebesar 0,946 atau $94,6 \%$ return on assets (ROA) dipengaruhi oleh perputaran piutang dan sisanya 5,4\% dipengaruhi faktor lain yang tidak diteliti.

3. Hasil Uji-t menunjukkan bahwa $t_{\text {hitung }}>t_{\text {tabel }}$ yakni uji $t_{\text {hitung }}$ sebesar $=8,407$ dengan taraf nyata $5 \%$, ini menunjukkan bahwa perputaran piutang mempunyai pengaruh signifikan pada perusahaan PT. Summarecon Agung Tbk. 


\section{DAFTAR PUSTAKA}

Bardiwan, Zaky (2011) Intermediate Accounting, Edisi 8. Yogyakarta : BPFE

Budiang, F. T., Pangemanan, S. S., \& Gerungai, N. Y. (2017). Pengaruh Perputaran Total Aset, Perputaran Piutang Dan Perputaran Persediaan Terhadap ROA Pada Perusahaan Sub Sektor Perdagangan Eceran Yang Terdaftar Di BEI. Jurnal EMBA: Jurnal Riset Ekonomi, Manajemen, Bisnis dan Akuntansi, 5(2).

Djarwanto (2011) Pokok-Pokok Analisis Laporan Keuangan, Edisi kedua. Yogyakarta: BPFE

Fess, Reeve, dan Warren (2008) Pengantar Akuntansi Edisi Ketiga. Jakarta: Salemba Empat

Hanafi, M. Mamduh dan Halim (2016) Analisis Laporan Keuangan Edisi Kelima. Yogyakarta :UPPSTIM YPKP

Kasmir (2008) Analisis Laporan Keuangan. Jakarta : Rajawali Pers.

Kasmir (2011) Analisis Laporan Keuangan. Jakarta : Raja Grafindo Persada

Kieso et al. (2007) Akuntansi Intermediate Terjemahan Emil Salim, Jilid 1, Edisi Kesepuluh. Jakarta : Erlangga

Martono dan Harjito (2011) Manajemen Keuangan Edisi Kedua Cetakan Pertama. Yogyakarta. Ekonisa

Munawir (2014) Analisis Laporan Keuangan. Jakarta : Liberty

Nugroho, L., Aryani, E., \& Mastur, A. A. (2019). Analisa Pengaruh Perputaran Kas dan Perputaran Piutang Terhadap Return on Asset (ROA) pada Perusahaan LQ 45 yang Terdaftar di BEI Tahun 2012-2017. Inovbiz: Jurnal Inovasi Bisnis, 7(1), 20-26.

Riyanto, Bambang (2016) Dasar-dasar pembelajaran perusahaan cetakan kelimabelas, Yogyakarta:BPFE.

Sartono, R. Agus. (2010) Manajemen Keuangan Teori dan Perencanaan Keuangan Perencanaan. Jakarta .PT. Gramedia Pustaka Utama

Sawir, Agnes (2005) Analisis Kinerja Keuangan dan Perencanaan Keuangan Perusahaan. Jakarta: Gramedia Pustaka.

Setiawan, Saryono (2010) Manajemen Keuangan. Yogyakarta: BPFE

Sugiyono (2012) Metode Penelitian Pendidikan Pendekatan Kuantitatif, Kualitatif dan $R \& D$ Cetakan Ke-13. Bandung : ALFABETA

Tandelilin, Eduardus (2010) Portofolio dan Inverstasi Teori dan Aplikasi, Edisi Pertama. Yogyakarta: KANISIUS

Tiong, P. (2017). Pengaruh Perputaran Piutang Terhadap Profitabilitas Pada Perusahaan PT Mitra Phinastika Mustika Tbk. SEIKO: Journal of Management \& Business, 1(1), 1-25.

Widasari, E., \& Apriyanti, S. (2017). PENGARUH PERPUTARAN KAS DAN PERPUTARAN PIUTANG TERHADAP RETURN ON ASSET (ROA). The Asia Pacific Journal Of Management Studies, 4(1). 